\title{
Viability of probiotic bacteria in tropical mango juice and the resistance of the strains to gastrointestinal conditions simulated in vitro
}

\section{Viabilidade de bactérias probióticas em suco tropical de manga e resistência das estirpes às condições gastrointestinais simuladas in vitro}

\author{
Lívia Ladeira Furtado'; Maurilio Lopes Martins ${ }^{2 *}$; Afonso Mota Ramos ${ }^{3}$; \\ Roselir Ribeiro da Silva²; Bruno Ricardo de Castro Leite Junior ${ }^{3}$; \\ Eliane Maurício Furtado Martins ${ }^{2}$
}

\begin{abstract}
This study evaluated the viability of Lactobacillus acidophilus La-05, Lactobacillus plantarum LP299v and Lactobacillus rhamnosus GG in tropical mango juice, the resistance of the strains to gastrointestinal conditions simulated in vitro and the microbiological, physicochemical and sensory characteristics of the products obtained. The viabilities of $L$. rhamnosus GG and L. plantarum LP299v were greater than $7.96 \log \mathrm{CFU} \mathrm{mL} \mathrm{m}^{-1}$ and $7.74 \log \mathrm{CFU} \mathrm{mL}{ }^{-1}$, respectively, during the 28 days of storage at $8^{\circ} \mathrm{C}$. However, there was a reduction $(\mathrm{p}<0.05)$ in the viability of $L$. acidophilus La-5 after 21 days of storage, with counts of $3.81 \log \mathrm{UFC} \mathrm{mL}^{-1}$. The parameters of $\mathrm{pH}$, total soluble solids, luminosity $\left(\mathrm{L}^{*}\right)$ and the color coordinates, $\mathrm{a}^{*}$ and $\mathrm{b}^{*}$, did not differ between the treatments. However, the $\mathrm{pH}$ and acidity varied during the storage time, probably due to the fermentative action of the microorganisms. For the in vitro gastrointestinal resistance test, there was a difference in the gastric phase for enteric phases I and II. The mean viability of the microorganisms in the gastric phase was $5.11 \log \mathrm{CFU} \mathrm{mL}^{-1}$, decreasing to 4.02 and $3.97 \log \mathrm{CFU} \mathrm{mL} \mathrm{m}^{-1}$ in enteric phases I and II, respectively. Juices containing L. rhamnosus GG and L. plantarum LP299 were evaluated sensorially, presenting good acceptability. The results suggest that the tropical mango juice was a good carrier matrix for L. rhamnosus GG and L. plantarum LP $299 \mathrm{v}$, being well accepted and therefore an alternative for populations with dietary restrictions.
\end{abstract}

Key words: Gastrointestinal resistance. Probiotic drink. Probiotic Lactobacillus. Tropical fruit.

\section{Resumo}

Este estudo avaliou a viabilidade de Lactobacillus acidophilus La-05, Lactobacillus plantarum LP299v e Lactobacillus rhamnosus GG em suco tropical de manga, a resistência das estirpes às condições gastrointestinais simuladas em ensaio in vitro e as características microbiológicas, físico-químicas e sensoriais dos produtos obtidos. A viabilidade de L. rhamnosus GG e L. plantarum LP299v foi superior a 7,96 $\log \mathrm{UFC} \mathrm{mL}^{-1}$ e 7,74 $\log \mathrm{UFC} \mathrm{mL} \mathrm{m}^{-1}$, respectivamente, ao longo dos 28 dias de armazenamento

1 Discente, Curso de Mestrado, Programa de Pós-Graduação em Ciência e Tecnologia de Alimentos, Instituto Federal do Sudeste de Minas Gerais, IF Sudeste MG, Rio Pomba, MG, Brasil. E-mail: livinha furtado@hotmail.com

2 Profs., Instituto Federal do Sudeste de Minas Gerais, IF Sudeste MG, Rio Pomba, MG, Brasil. E-mail: maurilio.martins@, ifsudestemg.edu.br; roselir.silva@ifsudestemg.edu.br; eliane.martins@ifsudestemg.edu.br

3 Profs., Universidade Federal de Viçosa, UFV, Viçosa, MG, Brasil. E-mail: amramos@ufv.br; brunorclj@gmail.com

* Author for correspondence 
a $8{ }^{\circ} \mathrm{C}$. Entretanto, houve redução $(\mathrm{p}<0,05)$ da viabilidade de L. acidophilus La-5 após 21 dias de armazenamento, com contagens de 3,81 log UFC mL $\mathrm{mL}^{-1}$. pH, sólidos solúveis totais, luminosidade (L*) e as coordenadas a* e b* não diferiram entre os tratamentos. Entretanto, houve diferença de $\mathrm{pH}$ e acidez ao longo do tempo de armazenamento provavelmente devido a ação fermentativa dos microrganismos. No ensaio in vitro de resistência gastrointestinal, houve diferença da fase gástrica para as fases entéricas I e II. A média da viabilidade dos microrganismos na fase gástrica foi de 5,11 log UFC $\mathrm{mL}^{-1}$, decaindo para 4,02 e 3,97 log UFC $\mathrm{mL}^{-1}$ nas fases entéricas I e II, respectivamente. Os sucos contendo $L$. rhamnosus GG e L. plantarum LP299 foram avaliados sensorialmente, apresentando boa aceitabilidade. Os resultados de viabilidade e resistência ao trato gastrointestinal simulado in vitro sugerem que o suco tropical de manga é uma ótima matriz carreadora de L. rhamnosus GG e L. plantarum LP 299v, sendo bem aceitos e, portanto, uma alternativa para a população que apresenta restrições na dieta.

Palavras-chave: Bebida probiótica. Fruta tropical. Lactobacillus probióticos. Resistência gastrointestinal.

\section{Introduction}

The need to incorporate healthy, ready-toeat and tasty foods into the diet has awakened the interest of the food industry to developing products that combine sensory characteristics with health-related properties (MARTINS et al., 2013). Fruits are rich in components that act beneficially in the human organism, being associated with the promotion of health and well-being, and reducing the risk of chronic diseases (MOREIRA et al., 2017; STRINGHETA et al., 2010). Amongst the diversity of fruits, the mango is highly appreciated because of its pleasant taste, and is of great economic importance to tropical countries.

In the context of functional foods, in addition to fruits containing bioactive compounds, there are also probiotics, which are live microorganisms that, when administered in adequate quantities, confer benefits on the health of the host (FAO/WHO, 2001; SANDERS, 2003). Although dairy products are good carriers of these microorganisms, there is a growing demand for non-dairy foods as carriers of probiotic microorganisms (MARTINS et al., 2015; RIVERA-ESPINOZA; GALLARDO-NAVARRO, 2010) due to populations presenting dietary restrictions, such as vegetarians and individuals with hypercholesterolemia, lactose intolerance and allergies to milk proteins (MARTINS et al., 2013, 2016).
However, in order to use them, probiotic microorganisms must be safe for the health and present in sufficient quantities at the time of consumption. It is also essential that the cultures survive the food processing operations, and survive in the food products to which they are finally added (TRIPATHI; GIRI, 2014). Finally, in order to take advantage of the beneficial action of the probiotic microorganisms in the intestine, they must be present in the product in significant concentrations and be able to survive the acid conditions of the stomach and the bile salts (CHAMPAGNE et al., 2011).

In the development of probiotic functional foods, the correct choice of the probiotic strain is of great importance, in order to be successful in the product, since the microorganism versus food matrix interaction should aid in the resistance of the probiotic during its passage through the gastrointestinal tract (BURNS et al., 2014; ESPÍRITO SANTO et al., 2011).

Thus, the study of the viability and resistance to gastrointestinal conditions simulated in vitro by different probiotic species and strains in a single carrier matrix is important, in order to choose the ideal microorganism for the product, since the probiotic culture must be present in elevated numbers throughout the shelf life of the product. The objective of the present study was to evaluate 
the viability of Lactobacillus acidophilus La-05, Lactobacillus plantarum LP299v and Lactobacillus rhamnosus GG in tropical mango juice and their resistance to gastrointestinal conditions simulated in vitro, as well as determining the microbiological, physicochemical and sensory characteristics of the products obtained.

\section{Material and Methods}

\section{Elaboration of the mango pulp}

Palmer mangoes in an optimum maturation stage for consumption were purchased at the local market in the city of Rio Pomba, MG, selected and washed under running water. The fruits were then sanitized in a sodium hypochlorite solution (200 $\mathrm{mg} \mathrm{L}^{-1}$ ) to eliminate contaminating microorganisms and rinsed in drinking water containing $10 \mathrm{mg} \mathrm{L}^{-1}$ active chlorine. They were subsequently peeled manually using stainless steel knives cut into pieces and shredded in a Walita processor (Model RI6720), obtaining a homogeneous pulp, which was evaluated for its $\mathrm{pH}$, titratable acidity, total soluble solids (TSS) (AOAC, 2010), ascorbic acid (ZENEBON; PASCUET, 2004), and color. It was then frozen in plastic bags at $-18{ }^{\circ} \mathrm{C}$ for later use in the preparation of the tropical juice.

\section{Elaboration of the tropical mango juice}

From the frozen fruit pulp, tropical juice containing $50 \%$ mango pulp, with the addition of sugar up to $11^{\circ}$ Brix, was produced, in order to comply with Normative Instruction $\mathrm{N}^{\circ} 12$ (BRASIL, 2003). After elaboration, $90 \mathrm{~mL}$ aliquots of the juice were bottled in $200 \mathrm{~mL}$ glass bottles and pasteurized in a water bath at $90{ }^{\circ} \mathrm{C}$ for 60 seconds, using as the control a bottle containing the juice and a thermometer for control of the temperature. After pasteurisation, the juice was cooled to room temperature.
Activation of the probiotic bacteria and inoculation into the tropical mango juice

For activation of the probiotic cultures, $5 \mathrm{~g}$ of L. acidophilus La-05 containing $10^{11}$ cells and two capsules of L. rhamnosus GG (Culturelle ${ }^{\circledR}$ ) and of L. plantarum LP299v (Jamieson ${ }^{\mathrm{TM}}$ ) containing $10^{10}$ cells were added individually under aseptic conditions, into the juice, and incubated for $24 \mathrm{~h}$ at $36{ }^{\circ} \mathrm{C}$ (New Ethics 403-5D, Brazil), characterizing the adaptation phase of the microorganism, in order to reach an inoculum with a count of approximately 9.0 - $8.0 \log \mathrm{CFU} \mathrm{g}^{-1}$ of probiotic bacteria in $100 \mathrm{~mL}$ of pasteurized juice.

After the incubation period, $10 \mathrm{~mL}$ aliquots of the pre-inoculums of L. acidophilus La-05, $L$. plantarum LP299v and L. rhamnosus GG were added individually under aseptic conditions to 90 $\mathrm{mL}$ of pre-pasteurized juice. The vials containing the juice were stored at $8{ }^{\circ} \mathrm{C}$ for up to 28 days, being evaluated for their microbiological and physicochemical characteristics, and for the resistance of the L. acidophilus La-05, L. plantarum LP299v and L. rhamnosus GG to simulated in vitro gastrointestinal conditions.

Evaluation of the viability of the probiotic cultures in the juice

The viability of probiotic cultures was determined in triplicate by deep plating in deMan, Rogosa and Sharpe Agar (MRS) according to Richer and Vedamuthu (2001). After incubation, the colony forming units (CFU) were counted to determine the population of probiotic bacteria in the product. The viability assessment was carried out immediately after juice elaboration (time 0 ) and after 3, 7, 14, 21 and 28 days of storage at $8{ }^{\circ} \mathrm{C}$ for all the treatments.

\section{In vitro simulation of gastrointestinal conditions}

The survival of $L$. acidophilus La-05, $L$. plantarum LP299v and L. rhamnosus GG was 
evaluated by simulating the gastric and enteric juices and enzymes of the gastrointestinal tract using an in vitro model, according to the methodology proposed by Bedani et al. (2013) at time 0 (after juice production, $0 \mathrm{~d}$ ) and after 14 and 28 days of storage $(14 \mathrm{~d}$ and $28 \mathrm{~d})$ at $8{ }^{\circ} \mathrm{C}$.

Evaluation of the microbiological quality of the juices

Tropical mango juices with added L. acidophilus La-05, L. plantarum LP299v or L. rhamnosus GG were analyzed immediately after preparation (time 0 ) and after four weeks of storage at $8{ }^{\circ} \mathrm{C}$ in order to evaluate the conformity of the products to the microbiological quality standards recommended by RDC N 12 (BRASIL, 2001).

Coliform analyses at $36{ }^{\circ} \mathrm{C}$ and at $45{ }^{\circ} \mathrm{C}$ were carried out according to Kornacki and Johnson (2001). The presence or absence of Salmonella sp. in $25 \mathrm{~mL}$ was determined according to the methodology of Andrews et al. (2001). The analysis of filamentous fungi and yeasts was carried out using $0.1 \%$ peptone-water as diluent and surface plating on Dichloran Rose Bengal Chloramphenicol Base Agar (Neogen, Indaiatuba, São Paulo, Brazil), incubating at $25{ }^{\circ} \mathrm{C}$ for five days according to Beuchat and Cousin (2001).

\section{Determination of $p H$, acidity and TSS}

The juices containing probiotic cultures were analyzed for $\mathrm{pH}$, titratable acidity, TSS and color, immediately after their elaboration (time 0 ), and after $3,7,14,21$ and 28 days of storage at $8{ }^{\circ} \mathrm{C}$. These analyses were applied to the juices according to AOAC (2010).

\section{Ascorbic acid}

Ascorbic acid was determined in the different treatments using Tillman's method according to
Zenebon and Pascuet (2004) for the times of 0, 7, 14,21 and $28 \mathrm{~d}$ of storage at $8{ }^{\circ} \mathrm{C}$. The results were expressed in milligrams of ascorbic acid per $100 \mathrm{~mL}$ of mango juice according to equation 1 .

$\mathrm{AA}=((\mathrm{V}-\mathrm{v}) \times \mathrm{F} \times 100) / \mathrm{A}$

Where:

$\mathrm{V}$ : the volume of Tillman's solution used to titrate the sample

$\mathrm{v}$ : the volume of Tillman's solution used to titrate the blank

F: the Tillman's solution factor

A: $\mathrm{mL}$ of sample

AA: $\mathrm{mg}$ ascorbic acid $100 \mathrm{~mL}^{-1}$ of juice

\section{Color determination}

In order to determine the color of the tropical juices, a direct reflectance reading of the $\mathrm{L}^{*}, \mathrm{a}^{*}$ and $\mathrm{b}^{*}$ coordinates was carried out using a colorimeter (Konica Minolta CR-10, Osaka, Japan) and the CIELAB scale of the International Commission of Lighting. Samples of the juices were transferred to borosilicate glass plates of about $3.0 \mathrm{~mm}$ thickness and the values for $L^{*}, a^{*}$ and $b^{*}$ of each sample obtained from the average of five consecutive readings at different points of the product.

\section{Sensory analysis}

The juices with the best cell viability after processing (containing L. rhamnosus GG and $L$. plantarum LP299) were evaluated for acceptability by 50 untrained testers, using a nine-point hedonic scale varying between "liked extremely " (score 9) and "disliked extremely" (score 1) for the attributes of flavor, color, aroma, acidity and overall impression, according to Minim (2013). The juice was served at room temperature in plastic cups with a capacity of $50 \mathrm{~mL}$, randomly encoded with three pre-set numbers. 
The project was approved by the Committee of Ethics in Research of the Federal Institute of Education of the Southeast of Minas Gerais State, with the emission of a Presentation Certificate of Ethical Appreciation (CAAE $\mathrm{n}^{\circ}$. 35283014.1.0000.5588).

\section{Statistical analysis}

The experiments were carried out with three repetitions, the physicochemical and microbiological evaluations and viability of the cultures were carried out in duplicate, while the in vitro simulation of gastrointestinal conditions was carried out in triplicate.

For the physicochemical analyses $(\mathrm{pH}$, acidity, color and TSS), the experiment was carried out using a completely randomized design (CRD) with a $3 \times 6$ factorial scheme (microorganisms $x$ time). The ascorbic acid content was evaluated by CRD with a $3 \times 5$ factorial scheme (microorganisms $x$ time) and the linear regression of each microorganism was carried out at the time of analysis. The probiotic viability experiments were carried out using a CRD with a $3 \times 6$ factorial scheme (microorganisms $x$ time). The study of the in vitro simulation of the gastrointestinal tract was carried out using a CRD with a $3 \times 3 \times 3$ factorial scheme (microorganism, phases and time). The acceptance test data of the sensory analysis for all the attributes were analyzed using a random block design (RBD) for two samples (tropical mango juice with added L. rhamnosus GG and tropical mango juice with added L. plantarum) and one time (immediately after processing). The results were evaluated by an analysis of variance and the means compared by the Tukey test at 5\% probability. All the analyses were carried out using the Free R Statistical Software (R Development Core Team, 2008) with the aid of the ExpDes packet (FERREIRA et al., 2011).

\section{Results and Discussion}

\section{Characteristics of the Palmer mango pulp}

The mango pulp presented the following characteristics: $11.7{ }^{\circ}$ Brix, $\mathrm{pH}$ value of 4.67 , titratable acidity of $0.081 \mathrm{~g}$ of citric acid per $100 \mathrm{~mL}$, $16.96 \mathrm{mg}$ of ascorbic acid per $100 \mathrm{~mL}$ and values for $\mathrm{L}^{*}, \mathrm{a}^{*}$ and $\mathrm{b}^{*}$ of 41.6, 5.0 and 23.2, respectively, it being necessary to adjust the $\mathrm{pH}$ value and acidity to conform with the Brazilian legislation.

Viability of the probiotic cultures in the tropical mango juice

L. rhamnosus GG and L. plantarum LP299v presented counts higher than $7.96 \log \mathrm{CFU} \mathrm{mL} \mathrm{mL}^{-1}$ and $7.74 \log \mathrm{CFU} \mathrm{mL}^{-1}$, respectively, throughout the 28 days of storage of the juices at $8{ }^{\circ} \mathrm{C}$, showing no difference $(p>0.05)$ in the viability of these cultures with time (Figure 1). Although there is no consensus on the minimum amount of probiotic microorganisms needed to provide beneficial effects to the organism (MARTINS et al., 2016), some authors consider a value of $>6 \log$ CFU $\mathrm{g}^{-1}$ or $\mathrm{mL}^{-1}$ of the food (HUSSAIN et al., 2016), whilst others consider between 6 and $7 \log \mathrm{CFU} \mathrm{g}^{-1}$ (MADUREIRA et al., 2011), or 9 to $10 \log$ CFU $\mathrm{g}^{-1}$ (NAIDU et al., 2012). A $100 \mathrm{~mL}$ portion of the tropical mango juice containing L. rhamnosus or $L$. plantarum carried at least $9.96 \log$ CFU or $9.74 \mathrm{log}$ CFU of these microorganisms, sufficient to promote health benefits to the host. 
Figure 1. Viability of L. acidophilus La-05, L. rhamnosus GG and L. plantarum LP299v in the tropical mango juices during 28 days of storage at $8{ }^{\circ} \mathrm{C}$. Values followed by the same letter do not differ statistically from each other according to the Tukey test at $5 \%$ probability for all the microorganisms with time.

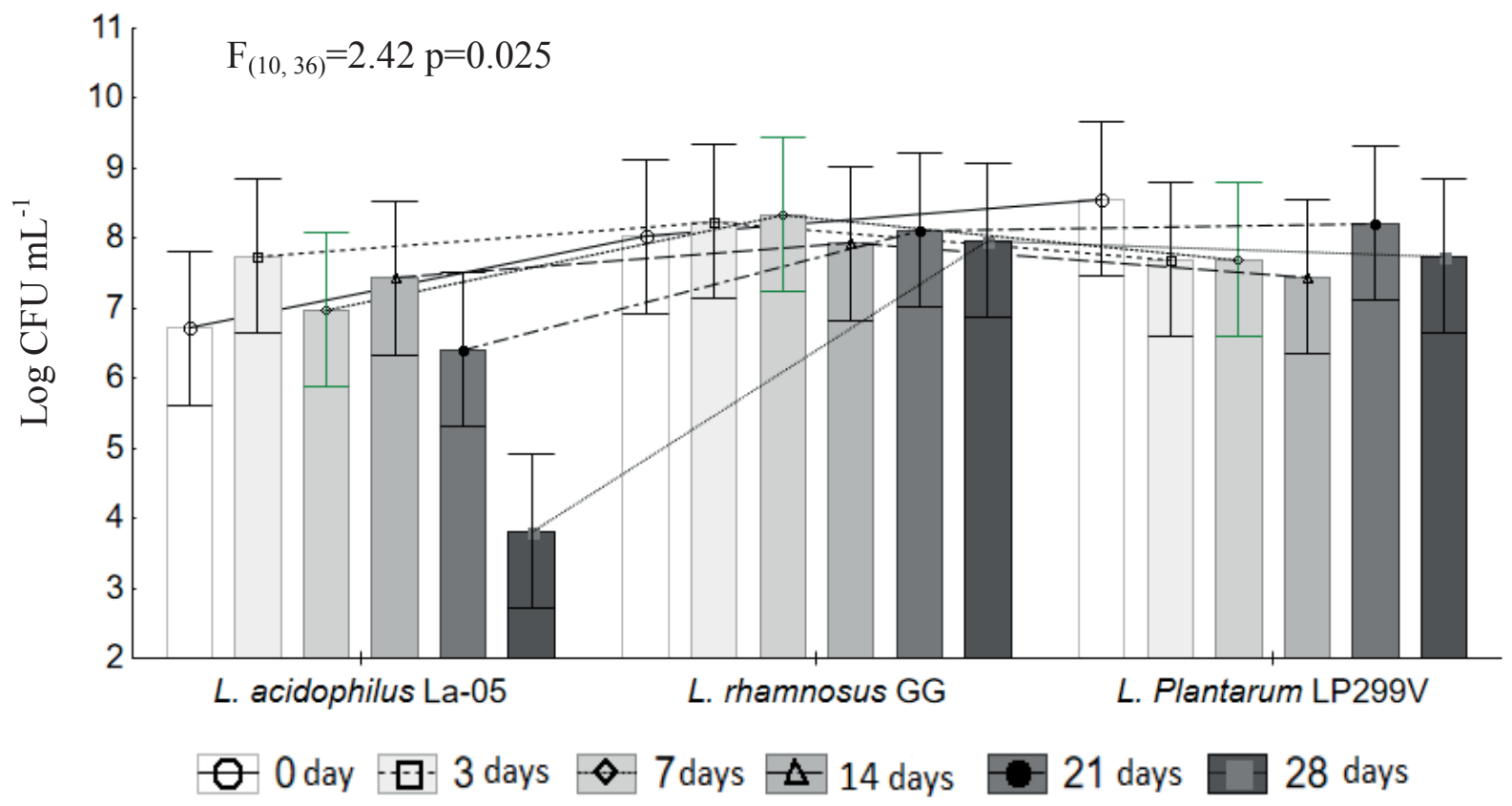

On the other hand, it was observed that the viability of $L$. acidophilus La-5 reduced $(\mathrm{p}<0.05)$ after 21 days of storage (Figure 1), reaching a count of $3.81 \log \mathrm{CFU} \mathrm{mL}-1$ at the end of the 28-day shelf life of the juice. Galgano et al. (2015) pointed out that not all probiotic strains produce good results in terms of survival when added to fruits and vegetables, which can be seen in the present study for $L$. acidophilus. It is believed that this reduction in the viability of $L$. acidophilus La-5 occurred due to the microorganism produce highly amount of acidic which could generate its inhibition.

Moreira et al. (2017) found that the count of $L$. rhamnosus $\mathrm{GG}$ was above $10^{8} \mathrm{CFU} \mathrm{mL}^{-1}$ during the 30 days of storage at $4{ }^{\circ} \mathrm{C}$ in a mixed juice of Ubá mango and jussara processed by a thermal process (pasteurization) and by high isostatic pressure (HIP), demonstrating its viability in the potentially probiotic product.

When developing functional probiotic foods, the selection of a suitable strain is critical to the

success of the product development, since the microorganism versus matrix interaction should aid in probiotic resistance during passage through the gastrointestinal tract (BURNS et al., 2014; ESPÍRITO SANTO et al., 2011). In addition, several other factors may influence probiotic viability, such as factors inherent to the food matrix (fat content, protein content, sugar composition, $\mathrm{pH}$ and the presence of antimicrobial substances) and factors related to processing (oxygen level, preservatives, temperature and storage time). Thus, the tropical mango juice can influence the resistance of the different microorganisms due to their physicochemical characteristics, since each strain has its own survival characteristics.

Survival of the probiotic strains to simulated in vitro gastrointestinal conditions

When evaluating the behavior of $L$. acidophillus La-05, L. plantarum LP299v and L. rhamnosus GG 
in the different phases of gastrointestinal conditions simulated in vitro during storage of the juices (Figure 2), significant interaction was found between the microorganism, phase and storage time, which was deployed for analysis (Figures 3A, 3B, 3C and 3D).

Figure 2. Survival of L. acidophillus La-05 (La-05), L. rhamnosus GG (LGG) and L. plantarum LP299v (LP) in the tropical mango juices during the gastrointestinal tract assay for 28 days at $8{ }^{\circ} \mathrm{C}$. Bars demonstrate the viability of the strains in the gastric, enteric I and enteric II gastrointestinal tract phases.

$$
\mathrm{F}_{(8,54)}=70.94 \mathrm{p}=0.00001
$$
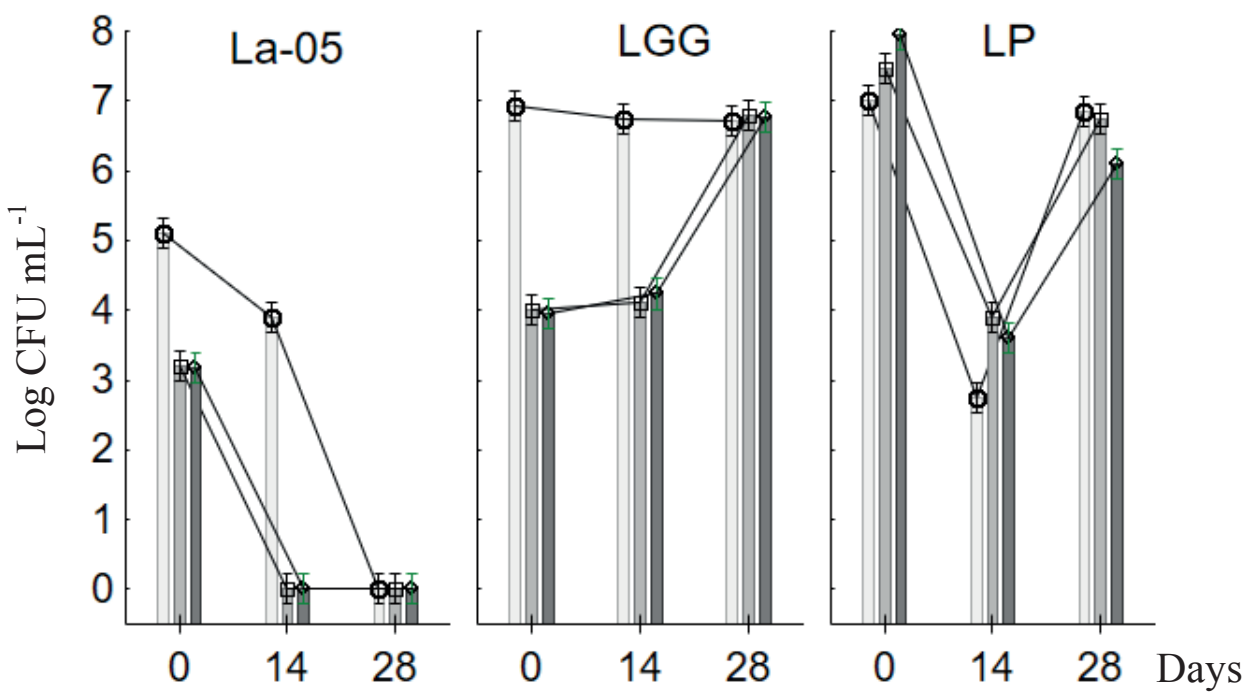

\section{O Gastric $\square$ Enteric I $\diamond$ Enteric II}

A difference was found $(\mathrm{p}<0.05)$ between the gastric phase and the enteric phases I and II (Figures $3 \mathrm{~A}$ and $3 \mathrm{C}$ ). The mean viability of the microorganisms in the gastric phase was $5.11 \mathrm{log}$ CFU mL $\mathrm{m}^{-1}$, falling to 4.02 and $3.97 \log \mathrm{CFU} \mathrm{mL} \mathrm{mL}^{-1}$ in enteric phases I and II, respectively (Figure 3A). There was also a difference in viability $(p<0.05)$ between the times (T0, T14 and T28) storage days of the juices (Figures 3B and 3D), decreasing between time 0 and time 14 days, followed by an increase for L. plantarum LP299v and L. rhamnosus GG between 14 and 28 days. This could be related to the sub-lethal stress applied to the microorganisms, which could have entered a viable but not culturable state and, in sequence, after adaptation, reassumed their growth. However, L. acidophillus La-05 did not show this behavior (Figure 3D). 
Figure 3. Development of the significant interaction (microorganism $\mathrm{x}$ storage time $\mathrm{x}$ phases of the in vitro GIT assay). A: Viability of the probiotic bacteria versus phases of the in vitro assay; B: Viability of the probiotic bacteria versus storage time of the juices; C: Viability of each probiotic bacterium versus phases of the in vitro assay; D: Viability of each probiotic bacterium versus storage time of the juices.
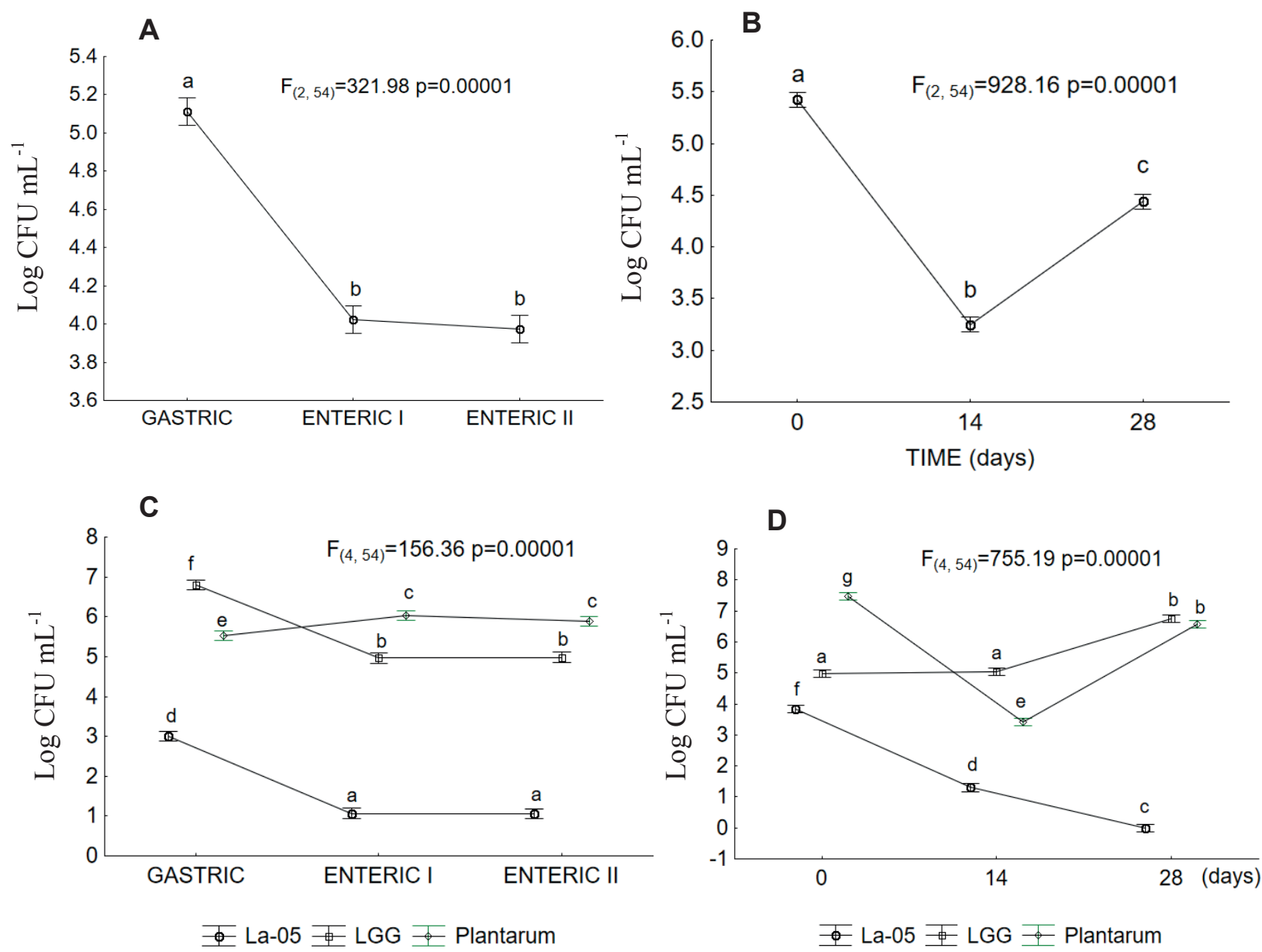

The results obtained by the present research group, such as those obtained by Oliveira et al. (2017) showed that the L. rhamnosus GG count in jaboticaba juice was $<1.0 \log \mathrm{CFU} \mathrm{mL}^{-1}$, estimated at the end of in vitro simulation, demonstrating the influence of the food matrix in the resistance of probiotic bacteria in the gastrointestinal tract.

When added to food, probiotic cultures should remain viable and in high concentrations, as from their inoculation and up to the end of the shelf life of the product, being able to survive gastrointestinal tract conditions, tolerating acidic conditions and bile salts, such that the food can be considered to

be probiotic (PERES et al., 2014). Madureira et al. (2011) considered that at least $10^{6}$ to $10^{7} \mathrm{CFU} \mathrm{g}^{-1}$ or $\mathrm{mL}^{-1}$ of viable probiotic cells should reach the intestinal colon for the food to have a therapeutic effect.

In the present study, L. plantarum LP299v and L. rhamnosus GG were more tolerant of most of the gastrointestinal tract stress factors. On average, from the viability of the microorganisms in enteric phase II of the gastrointestinal tract at all times of analysis, it can be inferred that the amount of viable cells that would reach the large intestine would be 1.06, 4.98 and 5.88 $\log$ CFU $\mathrm{mL}^{-1}$ for L. acidophillus 
La-05, L. rhamnosus GG and for L. plantarum LP299v, respectively. However, the consumption of a minimum of $100 \mathrm{~mL}$ of the tropical juices containing L. rhamnosus GG and L. plantarum would offer 6.98 and $7.88 \log$ CFU, respectively, sufficient to promote benefits to the host.

Although there are alternative technologies to protect microbial cells from gastrointestinal tract stress, such as encapsulation (HUQ et al., 2013), in the present work tropical mango juice was shown to be an excellent carrier matrix for the free cells of L. rhamnosus GG and L. plantarum LP299v. On the other hand, encapsulation technology represents a promising alternative to increase the viability of L. acidophillus La-05, protecting it from the acidic conditions of the stomach and allowing the cells to traverse this organ intact.

\section{Microbiological quality of the juices}

The quality and microbiological safety of juices depends on good manufacturing practices and efficient pasteurisation. The different treatments given to the tropical juice conformed to the Brazilian legislation (BRASIL, 2001) which established the standards for the microbiological safety of juices, soft drinks and other non-alcoholic drinks as being a maximum of $10 \mathrm{CFU} \mathrm{mL}-1$ of coliforms at $45^{\circ} \mathrm{C}$ and the absence of Salmonella sp. in $25 \mathrm{~mL}$ of the product.

Values of $<3.0 \times 10^{1} \mathrm{MPN} \mathrm{mL}^{-1}$ were found for total coliforms and E. coli and the absence of Salmonella sp. in $25 \mathrm{~mL}$ of the juices, indicating they were fit for human consumption. Regarding the yeast and filamentous fungi count, the treatments obeyed the maximum limit of $2.0 \times 10^{3} \mathrm{CFU} \mathrm{mL}^{-1}$ for chemically preserved pulp and/or that which was heat treated (BRASIL, 2001), since there is no legislation for the maximum limit in tropical juice.

\section{Physicochemical characteristics of the juices}

The $\mathrm{pH}$ values and TSS of the tropical mango juices with added $L$. acidophillus La-05, $L$. plantarum LP299v and L. rhamnosus GG did not differ significantly $(\mathrm{p}>0.05)$ (Table 1$)$. However, the acidity of the juice with added L. acidophillus La-05 differed $(p<0.05)$ from those of the other treatments (Table 1), which may be related to the lower viability of the strain.

Table 1. Mean values obtained for the $\mathrm{pH}$, total titratable acidity and total soluble solids of the mango juices containing probiotic bacteria at different storage times.

\begin{tabular}{lccc}
\hline \multirow{2}{*}{ Treatments } & \multicolumn{3}{c}{ Physicochemical characteristics } \\
\cline { 2 - 4 } & $\mathrm{pH}$ & Acidity & Total soluble solids ('Brix) \\
\hline Tropical juice + L. acidophillus La-05 & $3.820 \pm 0.156 \mathrm{a}$ & $0.296 \pm 0.108 \mathrm{~b}$ & $11.189 \pm 0.171 \mathrm{a}$ \\
Tropical juice + L. plantarum LP299v & $3.950 \pm 0.336 \mathrm{a}$ & $0.185 \pm 0.143 \mathrm{a}$ & $11.228 \pm 0.174 \mathrm{a}$ \\
Tropical juice + L. rhamnosus GG & $3.867 \pm 0.364 \mathrm{a}$ & $0.206 \pm 0.074 \mathrm{a}$ & $11.211 \pm 0.237 \mathrm{a}$ \\
\hline
\end{tabular}

Means followed by the same letter in the same column do not differ statistically from each other according to the Tukey test at $5 \%$ probability.

Probiotic bacteria from the same species were also studied by Martins et al. (2015) in fruit salad. These authors also observed a reduction in $\mathrm{pH}$ and an increase in the acidity of the product due to acid production. In the evaluation of $\mathrm{pH}$, a significant reduction was verified with time $(\mathrm{p}<0.05)$ (Figure $4 \mathrm{~A})$. However, time did not influence the acidity or TSS $(p>0.05)$ for any of the treatments (Figures 4B and $4 \mathrm{C})$. 
Figure 4. Values obtained for $\mathrm{pH}(\mathrm{A})$, total titratable acidity (B) and total soluble solids ( ${ }^{\circ}$ Brix) (C) of mango juices containing L. acidophillus La-05, L. rhamnosus GG and L. plantarum LP299v during 28 days of refrigerated storage.

A

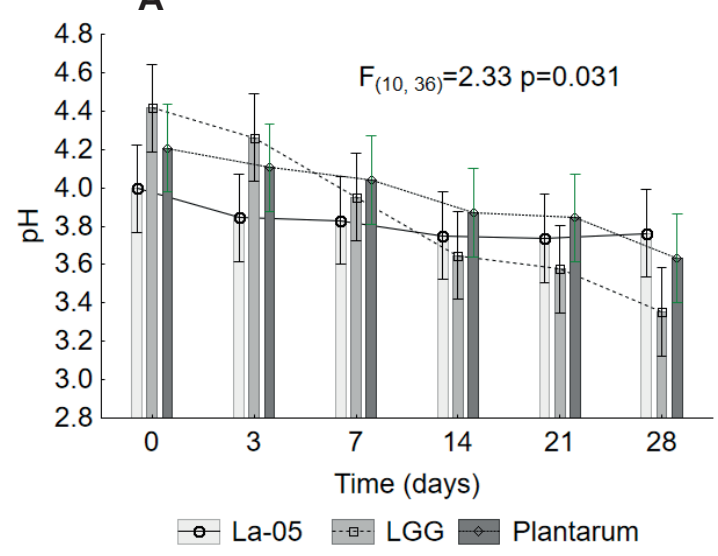

B

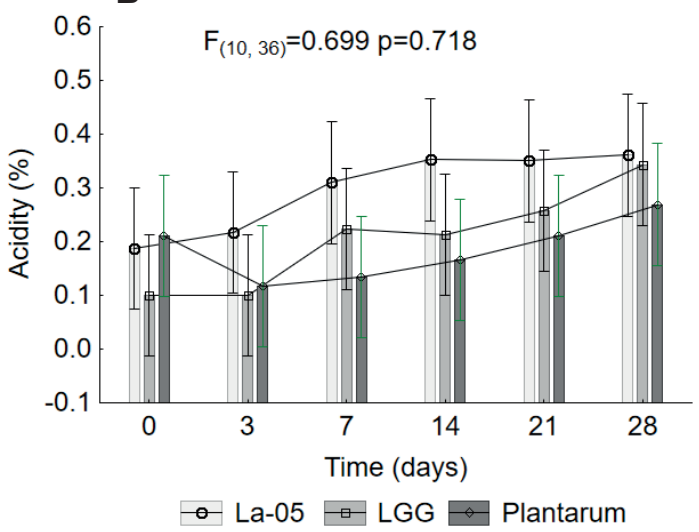

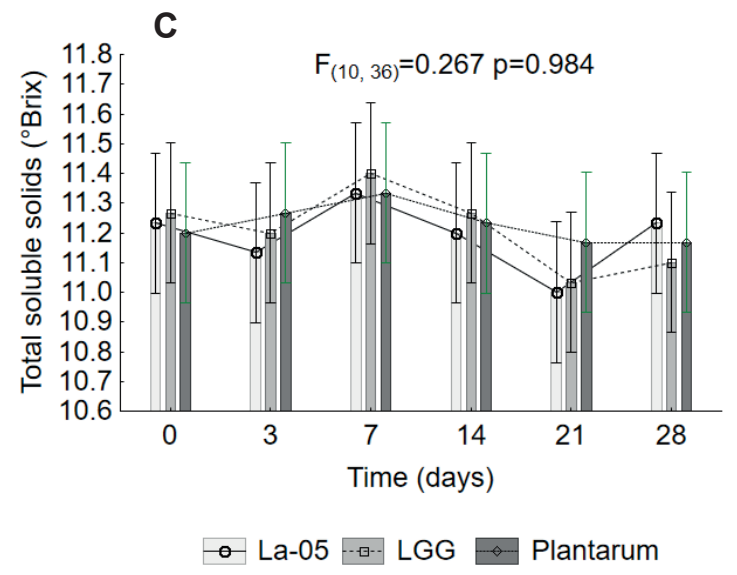

Ascorbic acid content

The tropical mango juice containing $L$. acidophillus La-05 presented a higher vitamin C content $(p<0.05)$ than the other treatments (Table 2). Considering the results obtained, the consumption of $130 \mathrm{~mL}$ of tropical juice containing L. acidophillus soon after processing was recommended in order to acquire the recommended daily amount of vitamin C, since, according to RDC n. ${ }^{\circ} 269$ of the National Health Surveillance Agency (ANVISA), the recommended intake of vitamin $\mathrm{C}$ is $45 \mathrm{mg}$ day $^{-1}$ (BRASIL, 2005). However, with age and according to the health conditions, the Recommended Daily Intake (RDI) is variable.

Table 2. Mean results obtained for the ascorbic acid content $\left(\mathrm{mg} 100 \mathrm{~g}^{-1}\right)$ in the mango juices containing L. rhamnosus GG, L. plantarum LP299v and L. acidophillus La-05, during 28 days of storage at $8^{\circ} \mathrm{C}$.

\begin{tabular}{lc}
\hline Treatments & Ascorbic acid \\
\hline Tropical juice + L. rhamnosus GG & $5.980 \mathrm{a}$ \\
Tropical juice + L. plantarum LP299v & $7.151 \mathrm{a}$ \\
Tropical juice + L. acidophillus La-05 & $20.040 \mathrm{~b}$ \\
\hline
\end{tabular}

Means followed by the same letter in the same column do not differ statistically from each other according to the Tukey test at $5 \%$ probability. 
With respect to the ascorbic acid content of the the factors of treatment and time ( $p>0.05)$. Thus, a mango juice there was no difference in relation to storage time $(\mathrm{p}>0.05)$ and no interaction between regression model was fitted for each treatment as a function of time (Figure 5).

Figure 5. Regression equations and coefficients of determination for the ascorbic acid contents of mango juices containing L. rhamnosus GG, L. plantarum LP299v and L. acidophilus La-5 during 28 days of refrigerated Storage.

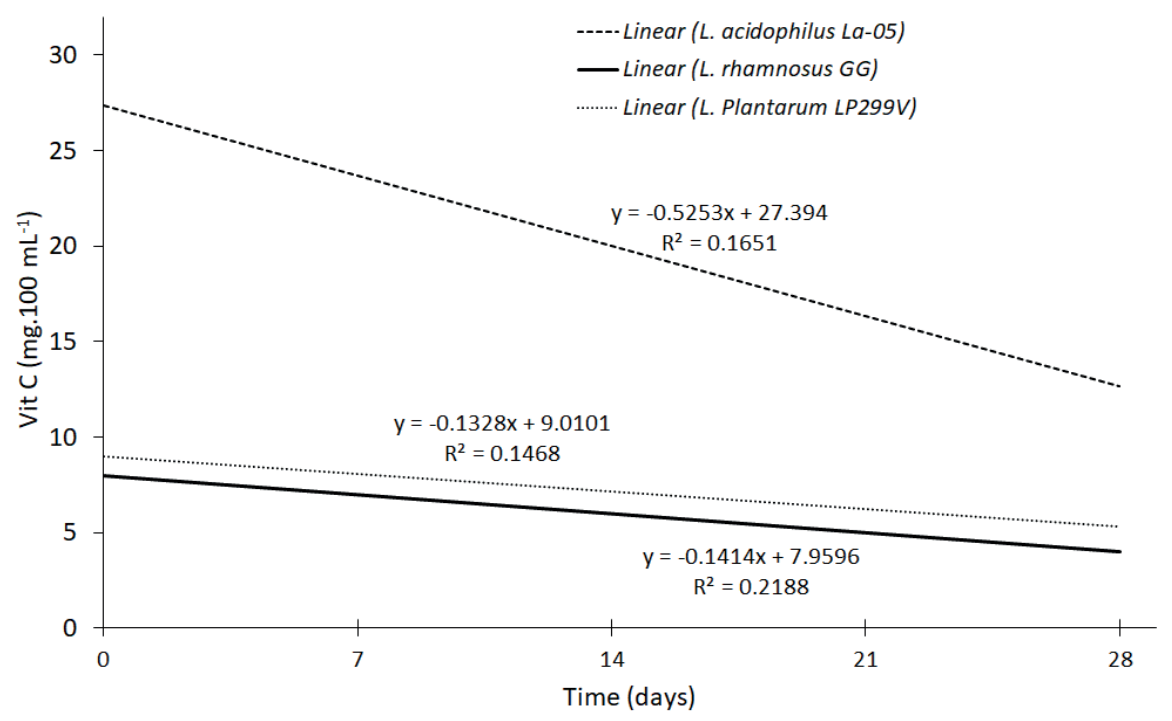

\section{Juice color}

Color is a characteristic that indicates the sensory quality of food products on the market, being of great importance in acceptance (WU et al., 2013). There was no difference $(p>0.05)$ for luminosity $\left(\mathrm{L}^{*}\right)$ or for the coordinates of $\mathrm{a}^{*}$ and $\mathrm{b}^{*}$ between treatments, or throughout storage (Table 3), showing that the probiotic microorganisms did not alter the color of the juices. The positive values obtained for the $b^{*}$ coordinate indicated predominance of a desirable yellow color in the mango juice, characteristic of the product, which is due to the presence of carotenoids.

Table 3. Mean results for $\mathrm{L}^{*}$ and the color coordinates $\mathrm{a}^{*}$ and $\mathrm{b}^{*}$ in the tropical mango juices containing probiotic bacteria.

\begin{tabular}{lccc}
\hline \multirow{2}{*}{ Treatments } & \multicolumn{3}{c}{ Color coordinates } \\
\cline { 2 - 3 } & $\mathrm{L}^{*}$ & $\mathrm{a}^{*}$ & $1.322 \mathrm{a}$ \\
\hline Tropical juice + L. acidophillus La-05 & $38.644 \mathrm{a}$ & $1.455 \mathrm{a}$ & $17.322 .383 \mathrm{a}$ \\
Tropical juice + L. plantarum LP299v & $36.833 \mathrm{a}$ & $1.355 \mathrm{a}$ & $16.38 \mathrm{a}$ \\
Tropical juice + L. rhamnosus GG & $36.844 \mathrm{a}$ & $1.127 \mathrm{a}$ & $15.488 \mathrm{a}$ \\
\hline
\end{tabular}

Means followed by the same letter in the same column do not differ statistically from each other according to the Tukey test at $5 \%$ probability.

Different from the present study, Costa et al. (2017) observed that the addition of L. paracasei and oligofructose to orange juice promoted darkening with a consequent loss of the yellow color, compromising acceptability of the product by consumers. 
Sensory analysis of the juices

There was no significant difference $(\mathrm{p}>0.05)$ between the mango juices containing $L$. rhamnosus GG and L. plantarum LP299v for the attributes evaluated (Table 4). Both juices were well accepted, indicating that the addition of probiotic cultures did not affect the sensory quality of the product after processing. Khezri et al. (2016) also observed no differences $(\mathrm{p}>0.05)$ in the attributes of flavor, odor, consistency and overall impression between fig juices containing L. plantarum DSMZ 20179 and $L$. delbrueckii DSMZ 15996.

Table 4. Mean results obtained in the sensory evaluation of the tropical mango juices containing L. rhamnosus GG and L. plantarum LP299v.

\begin{tabular}{lccccc}
\hline Treatments & Taste & Color & Acidity & Aroma & Global evaluation \\
\hline Tropical juice + L. plantarum LP299v & $7.56 \mathrm{a}$ & $8.10 \mathrm{a}$ & $7.64 \mathrm{a}$ & $7.54 \mathrm{a}$ & $7.76 \mathrm{a}$ \\
Tropical juice + L. rhamnosus GG & $7.52 \mathrm{a}$ & $8.12 \mathrm{a}$ & $7.56 \mathrm{a}$ & $7.44 \mathrm{a}$ & $7.78 \mathrm{a}$ \\
\hline
\end{tabular}

Means followed by the same letter in the same column do not differ statistically from each other according to the Tukey test at $5 \%$ probability.

\section{Conclusion}

Tropical mango juice can be considered a good vehicle for L. rhamnosus GG and L. plantarum LP299v, since the counts were higher than those required by some authors to promote health benefits for the host. The in vitro gastrointestinal tract resistance test showed that $6.76 \log \mathrm{CFU} \mathrm{mL}-1$ of L. rhamnosus GG and $6.09 \log \mathrm{CFU} \mathrm{mL} \mathrm{m}^{-1}$ of $L$. plantarum LP299V arrived at enteric stage II in the viable state, indicating the potentiality of the carrier matrix. On the other hand, the tropical mango juice was not a good matrix to transport L. acidophillus La-05.

In addition, the tropical mango juices were suitable for human consumption, and the presence of L. rhamnosus GG and L. plantarum LP299V did not change the color or physicochemical characteristics of the juice. Only the $\mathrm{pH}$ value changed with time, which may have promoted increased resistance of the surviving $L$. rhamnosus GG and L. plantarum LP299V cells, positively influencing the resistance of these microorganisms to the in vitro gastrointestinal tract test, different from the tropical juice containing $L$. acidophillus La-05 which showed the smallest $\mathrm{pH}$ change, and therefore presented lower viability and resistance in the in vitro assay. The tropical mango juices with added L. rhamnosus GG and L. plantarum LP299v were well accepted by the consumers, being a promising product for the juice market due to its functional appeal.

\section{Acknowledgements}

The authors are grateful to the Brazilian Science and Technology Research Council (CNPq, Brazil), to the Research Foundation of the State of Minas Gerais (FAPEMIG, Brazil), to the PET Group of Agricultural Sciences, and to the Federal Institute of the Southeast of Minas Gerais, for their financial support.

\section{References}

ANDREWS, W. H.; FLOWER, R. S.; SILLIKER, J.; BAILEY, J. S. Salmonella. In: DOWNES, F. P.; ITO, K. (Ed.). Compendium of methods for the microbilological examination of foods. $4^{\text {th }}$ ed. Washington: American Public Health Association, APHA, 2001. p. 357-380.

ASSOCIATION OF OFFICIAL ANALITICAL CHEMISTS - AOAC. Official methods of analysis of the AOAC. $18^{\text {th }}$ ed. Washington: Association of Analytical Communities, 2010. 
BEDANI, R.; ROSSI, E. A.; SAAD, S. M. Impact of inulin and okara on Lactobacillus acidophilus La-5 and Bifidobacterium animalis $\mathrm{Bb}-12$ viability in a fermented soy product and probiotic survival under in vitro simulated gastrointestinal conditions. Food Microbiology, London, v. 34, n. 2, p. 382-389, 2013.

BEUCHAT, L. R.; COUSIN, M. A. Yeasts and molds. In: DOWNES, F. P.; ITO K. (Ed.). Compendium of methods for microbilological examination of foods. $4^{\text {th }}$ ed. Washington: American Public Health Association APHA, 2001. p. 209-215.

BRASIL. Ministério da Agricultura, Pecuária e Abastecimento. Instrução Normativa $n .{ }^{\circ} 12$, de 4 de setembro de 2003. Aprova o regulamento técnico para fixação dos padrões de identidade e qualidade gerais para suco tropical e os padrões de identidade e qualidade dos néctares. Diário Oficial [da] União, Brasília, 9 set. 2003. Seção 1, p. 2.

Ministério da Saúde. Agência Nacional de Vigilância Sanitária. Resolução RDC n. ${ }^{\circ} 12$, de 2 de janeiro de 2001. Aprova o Regulamento técnico sobre padrões microbiológicos para alimentos. Diário Oficial [da] União, Brasília, 10 jan. 2001. Seção 1, p. 45-53.

Ministério da Saúde. Agência Nacional de Vigilância Sanitária. Resolução RDC n. ${ }^{\circ} 269$, de 22 de setembro de 2005. Regulamento técnico sobre Ingestão Diária Recomendada (IDR) de proteínas, vitaminas e minerais. Diário Oficial [da] União, Brasília, 23 de set. 2005. p. 35-43.

BURNS, P.; LAFFERRIERE, L.; VINDEROLA, G.; REINHEIMER, J. Influence of dairy practices on the capacity of probiotic bactéria to overcome simulated gastric digestion. International Journal of Dairy Technology, Huntingdon, v. 67, n. 3, p. 448-457, 2014.

CHAMPAGNE, C. P.; ROSS, R. P.; HANSEN, K. F.; CHARALAMPOPOULOS, D. Recommendations for the viability assessment of probiotics as concentrated cultures and in food matrices. International Journal of Food Microbiology, London, v. 149, n. 3, p. 185-193, 2011.

COSTA, G. M.; SILVA, J. V. C.; MINGOTTI, J. D.; BARÃO, C. E.; KLOSOSKI, S. J.; PIMENTEL, T. C. Effect of ascorbic acid or oligofructose supplementation on $L$. paracasei viability, physicochemical characteristics and acceptance of probiotic orange juice. LWT - Food Science and Technology, Amsterdam, v. 75, p. 195-201, 2017.

ESPÍRITO SANTO, A. P.; PEREGO, P.; CONVERTI, A.; OLIVEIRA, M. O. Influence of food matrices on probiotic viability- A review focusing on the fruity bases. Trend in Food Science \& Technology, London, v. 22, n. 7, p. 377-385, 2011.

FERREIRA, E. B.; CAVALCANTI, P. P.; NOGUEIRA, D. A. Experimental designs: um pacote R para análise de experimentos. Revista de Estatística da UFOP, Ouro Preto, v. 1, n. 1, p. 1-9, 2011.

FOOD AND AGRICULTURE ORGANIZATION OF THE UNITED NATIONS; WORLD HEALTH ORGANIZATION - FAO/WHO. Evaluation of health and nutritional properties of probiotics in food including powder milk with live lactic acid bacteria. Córdoba: Report of a Joint FAO/WHO Expert Consultation, 2001. $34 \mathrm{p}$.

GALGANO, F.; CONDELLI, N.; CARUSO, M. C.; COLANGELO, M. A.; FAVATI, F. Probiotics and prebiotics in fruits andvegetables: technological and sensory aspects. In: RAI, V. R.; BAI, J. A. (Ed.). Beneficial microbes in fermented and functional foods. Boca Raton, London: CRC Press, 2015. p. 189-206.

HUQ, T.; KHAN, A.; KHAN, R. A.; RIEDL, B.; LACROIX, M. Encapsulation of probiotic bacteria in biopolymeric system. Critical Reviews in Food Science and Nutrition, London, v. 53, n. 9, p. 909-916, 2013.

HUSSAIN, S. A.; PATIL, G. R.; YADAV, V.; SINGH, R. R. B.; SINGH, A. K. Ingredient formulation effects on physico-chemical, sensory, textural properties and probiotic count of Aloe vera probiotic dahi. LWT - Food Science and Technology, Amsterdam, v. 65, p. 371-380, 2016.

KHEZRI, S.; DEHGHAN, P.; MAHMOUDI, R.; JAFARLOU, M. Fig juice fermented with lactic acid bacteria as a nutraceutical product. Pharmacentical Sciences, Tabriz, v. 22, n. 4, p. 260-266, 2016.

KORNACKI, J. L.; JOHNSON, J. L. Enterobacteriaceae, coliforms, and Escherichia coli as quality and safety. In: DOWNES, F. P.; ITO, K. (Ed.). Compendium of methods for the microbiological examination of foods. $4^{\text {th }}$ ed. Washington: American Public Health Association, APHA, 2001. p. 9-81.

MADUREIRA, A. R.; AMORIM, M.; GOMES, A. M.; PINTADO, M. E.; MALCATA, F. X. Protective effect of whey cheese matrix on probiotic strains exposed to simulated gastrointestinal conditions. Food Research International, Amsterdam, v. 44, n. 1, p. 465-470, 2011.

MARTINS, E. M. F.; RAMOS, A. M.; MARTINS, M. L.; LEITE JÚNIOR, B. R. C. Fruit salad as a new vehicle for probiotic bacteria. Food Science and Technology, London, v. 36, n. 3, p. 540-548, 2016. 
MARTINS, E. M. F.; RAMOS, A. M.; MARTINS, M. L.; RODRIGUES, M. Z. Research and development of probiotic products from vegetable bases: a new alternative for consuming functional food. In: RAI, V. R.; BAI, J. A. (Ed.). Beneficial microbes in fermented and functional foods. Boca Raton, London: CRC Press, 2015. p. 207-223.

MARTINS, E. M. F.; RAMOS, A. M.; VANZELA, E. S. L.; STRINGHETA, P. C.; PINTO, C. L. O.; MARTINS, J. M. Products of vegetable origin: a new alternative for the consumption of probiotic bacteria. Food Research International, Amsterdam, v.51, n. 2, p. 764-770, 2013.

MINIM, V. P. R. Análise sensorial: estudos com consumidores. $3^{\text {th }}$ ed. Viçosa, MG: UFV, 2013. $332 \mathrm{p}$.

MOREIRA, R. M.; MARTINS, M. L.; LEITE JUNIOR, B. R. C.; MARTINS, E. M. F.; RAMOS, A. M.; CRISTIANINI, M.; CAMPOS, A. N. R.; STRINGHETA, P. C.; SILVA, V. R. O.; CANUTO, J. W.; OLIVEIRA, D. C.; PEREIRA, D. C. S. Development of a juçara and Ubá mango juice mixture with added Lactobacillus rhamnosus GG processed by high pressure. LWT - Food Science and Technology, Amsterdam, v. 77, p. 259-268, 2017.

NAIDU, K. S. B.; ADAM, J. K.; GOVENDER, P. The use of probiotics and safety concerns: a review. African Journal of Microbiology Research, Nairobi, v. 6, n. 41, p. 6871-6877, 2012.

OLIVEIRA, D. C.; MARTINS, E. M. F.; MARTINS, M. L.; MARTINS, G. B.; BINOTI, M. L.; CAMPOS, A. N. R.; RAMOS, A. M.; SILVA, M. H. L.; STRINGHETA, P. C. Efeito do branqueamento nos compostos bioativos e na viabilidade de Lactobacillus rhamnosus GG antes e após simulação in vitro do sistema digestivo em suco de jabuticaba. Semina: Ciências Agrárias, Londrina, v. 38, n. 3, p. 1277-1294, 2017.

PERES, C. M.; ALVES, M.; HERNÁNDEZMENDOZA, A.; MOREIRA, L.; SILVA, S.; BRONZE, M. R.; VILAS-BOAS, L.; PERES, C.; MALCATA, F. X.
Novel isolates of lactobacilli from fermented Portuguese olive as potential probiotics. LWT - Food Science and Technology, Amsterdam, v. 59, p. 234-246, 2014.

R DEVELOPMENT CORE TEAM. A language and environment for statistical computing. R Foundation for Statistical Computing. Vienna: The R Foundation for Statistical Computing, 2008. Available at: <http:// www.R-project.org.>. Accessed at: 1 nov. 2015.

RICHER, R. L.; VEDAMUTHU, E. R. Milk and milk products. In: DOWNES, F. P.; ITO, K. (Ed.). Compendium of methods for the microbiological examination of foods. $4^{\text {th }}$ ed. Washington: American Public Health Association, APHA, 2001. p. 483-496.

RIVERA-ESPINOSA, Y.; GALLARDO-NAVARRO, Y. Non-dairy probiotic products. Food Microbiology, London, v. 27, n. 1, p. 1-11, 2010.

SANDERS, M. E. Probiotics: considerations for human health. Nutrition Reviews, Oxford, v. 61, n. 3, p. 91-99, 2003.

STRINGHETA, P. C.; VOLP, A. C. P.; OLIVEIRA, T. T. Parte I - corantes naturais: usos e aplicações como compostos bioativos. In: COSTA, N. M. B.; ROSA, C. O. B. (Ed.). Alimentos funcionais: componentes bioativos e efeitos fisiológicos. Rio de Janeiro: Rubio: [s.n.], 2010. p. 243-261.

TRIPATHI, M. K.; GIRI, S. K. Probiotic functional foods: Survival of probiotics during processing and storage. Journal of Functional Foods, St. John's, v. 9, p. 225-241, 2014.

WU, S. P.; LONGO, C.; KENNELLY,E. J.Phytochemistry and health benefits of jaboticaba, an emerging fruit crop from Brazil. Food Research International, Amsterdam, v. 54, n. 1, p. 148-159, 2013.

ZENEBON, O.; PASCUET, N. S. Métodos fisicoquímicos para análise de alimentos. 4. ed. São Paulo: Instituto Adolfo Lutz, 2004. 1004 p. 